\title{
The analysis of the condition of colostral immunity of sows after vaccination against porcine epidemic diarrhea virus
}

\author{
O. Y. Ayshpur, I. Y. Mushtuk, L. M. Muzykina, O. A. Tarasov, \\ O. M. Yermolenko, V. V. Gumeniuk, M. M. Derevyanko \\ olenaayshpur@gmail.com, mushtuk0104@gmail.com \\ The Institute of Veterinary Medicine NAAS, \\ 30 Donetska str., Kyiv, 03151, Ukraine
}

Porcine epidemic diarrhea (PED) is an acute, highly contagious viral disease of pigs of all age groups, but it is manifested by particularly high mortality of newborn piglets and characterized by vomiting, diarrhea, and lack of appetite. Porcine epidemic diarrhea (PED) remains a problem for pig farms in many countries, including Ukraine. Specific prophylaxis PED had proven to be a difficult task and despite many studies, the problem of PED remains unresolved. Since piglets get infected during the first days after birth, their protection can only be provided by colostral antibodies of immuned sows. Therefore, the urgent task of veterinary medicine scientists is to develop effective methods of preventing the disease, which is to use local strains of the pathogen. The article presents the results of studies of colostral immunity of piglets by determining the presence of antibodies against the PED virus in the colostrum of sows who were immunized with a vaccine inactivated against PED from the intestinal virus of artificially infected suckling piglets. Infectious activity of matrix broods of the virus for the production of the preparation was determined by RT-PCR. According to the results of research, material was selected for the manufacture of the vaccine. Subsequently, the drug was monitored according to technological regulations, including the infectious activity of the virus, which ranged from $1.96 \times 10^{-8}$ to $3.16 \times 10^{-9}$. We conducted a comparative study of the presence of antibodies to the PED virus in the colostrum of sows in the treatment of animals by "back-feeding" and vaccination of sows with inactivated preparation. Samples of colostrum from sows were taken within 1-4 hours after farrowing. The article presents research results that allow us to conclude that both methods of treatment of sows create immunity in newborn piglets. Thus, the presence of antibodies to the PED virus in colostrum in the first hours after birth provide protection against infection and death.

Keywords: porcine epidemic diarrhea virus, pigs, colostral immunity, colostrum

Swine epidemic diarrhea virus (PEDV) is the RNAcontaining virus that belongs to the Coronaviridae family, a subgenus of Coronavirinae, of the genus Alphacoronavirus [4]. PEDV was first found in piglets and fattening pigs in England and was identified and recognized as the causative agent of epidemic diarrhea of pigs in 1978 [9]. The main clinical sign of PED was profuse diarrhea with $100 \%$ morbidity and $50-100 \%$ death of newborns and piglets under oneweek age with a decrease in the incidence of piglets and pigs of older age groups. PED outbreaks were reported from various countries in Europe and Asia, including Japan, China, South Korea, and Thailand [8]. Since 2010, an increase of this disease outbreaks has been reported by several provinces in China, which cause significant economic losses. The reason for this situation was the new strains of the PED virus, confirmed by isolation and characterization of virus [7].

PEDV was initially found in the eastern region of the Midwest USA in April 2013 [2]. The rapid dissemination of the virus was confirmed by virus isolation in diagnostic laboratories. During the period of 4-8 weeks after the virus was detected in first time, the number of states with PED outbreaks increased from 6 to 12. The greatest number of positive results were obtained in the states of lowa and Oklahoma. Subsequently, the PED virus was spreading extremely rapidly and was detected in June 2014 in 30 states of the United States [2]. 
In the summer of 2014, the first outbreak was registered in Ukraine. And in 2015, an outbreak of PED with a high incidence and mortality rate was also recorded at a large complex for growing pigs in Ukraine [1]. The virus was identified as the American type and unlike the European one, it has the highest pathogenicity.

The aim of our study was to study the status of colostral immunity of pigs by determining the presence of antibodies against the PED virus in the colostrum of sows immunized with a inactivated vaccine against PED on the basis of viral antigen obtained with infected dairy pigs $[3,5,6]$.

\section{Materials and Methods}

An experimental series of inactivated vaccines against PED with viral antigen obtained from infected dairy pigs were manufactured at the Institute of veterinary medicine NAAS in accordance with the developed process regulations. Infected intestines as a raw material for the manufacture of vaccines were obtained from a specialized diagnostic laboratory in compliance with all the rules for the delivery of such material. The level of antibodies in the colostrum of grafted sows was determined using the AntiGen PED IgA ELISA test kit.

Infectious activity of matrix rosperd virus to produce the drug was determined by real-time PCR.

\section{Results and Discussion}

The infectious activity of virus culture matrix for the vaccine production was determined by real time PCR.

The results of studies on the RNA titer of swine endemic diarrhea virus (EMF) (table 1).

According to the results of research, biological material was selected to produce vaccine. The vaccine was controlled according to the technological regulations, including the infectious activity of the virus, which ranged from $1.96 \times 10^{-8}$ to $3.16 \times 10^{-9}$.

It was carried out a comparative study of PED antibodies prevalence in the colostrum of sows treated with standard approaches and sows immunized with inactivated vaccines against PED. Colostrum from sows was collected within 1-4 hours after farrowing.

The titer of maternal antibodies in sows' colostrum (table 2).

The results of our research suggested that both methods of treating sow able to create protective immunity of newborn piglets. Thus, the presence of antibodies to the PED virus in colostrum from the first hours after farrow provides protection against PED infection and death of piglets. So, despite the high contagiousness of the disease and the variability of the PED virus, the choice of the preventing means and
Table 1. Infectious activity of virus culture matrix for the vaccine production (using real-time PCR)

\begin{tabular}{|c|c|c|}
\hline No. & Biological material & Results \\
\hline 1. & Pig intestinal suspension & $\begin{array}{c}\text { Titer of PED virus RNA } \\
\text { G.U. in } 1 \mathrm{ml} \\
\text { of biological material }\end{array}$ \\
\hline 2. & Pig intestinal suspension & $1.96 \times 10^{-8}$ \\
\hline 3. & Pig intestinal suspension & $5.06 \times 10^{-8}$ \\
\hline 4. & Pig intestinal suspension & $1.09 \times 10^{-9}$ \\
\hline 5. & Pig intestinal suspension & $1.51 \times 10^{-9}$ \\
\hline 6. & Pig intestinal suspension & $3.96 \times 10^{-8}$ \\
\hline 7. & Pig intestinal suspension & $9.33 \times 10^{-8}$ \\
\hline 8. & Pig intestinal suspension & $6.46 \times 10^{-8}$ \\
\hline 9. & Pig intestinal suspension & $3.16 \times 10^{-9}$ \\
\hline 10. & Pig intestinal suspension & $1.00 \times 10^{-9}$ \\
\hline & & $4.67 \times 10^{-8}$ \\
\hline
\end{tabular}

Table 2. The results of studies of the titers of maternal antibodies $(\lg \mathrm{A})$ in the colostrum of sows with different methods of prophylaxis treatment

\begin{tabular}{|c|c|c|c|c|}
\hline \multirow{2}{*}{ No. } & \multirow{2}{*}{$\begin{array}{l}\text { No. of sow, } \\
\text { no. of farm }\end{array}$} & \multirow{2}{*}{ Treatment } & \multicolumn{2}{|c|}{$\begin{array}{c}\text { Colostral antibody } \\
\text { titer }\end{array}$} \\
\hline & & & $\begin{array}{l}\text { Optical } \\
\text { density }\end{array}$ & Result \\
\hline 1. & $\begin{array}{c}1 \\
\text { farm no. } 1\end{array}$ & $\begin{array}{l}\text { reverse feeding } \\
\text { method }\end{array}$ & 0.309 & Negative \\
\hline 2. & $\begin{array}{c}2, \\
\text { farm no. } 1\end{array}$ & $\begin{array}{l}\text { reverse feeding } \\
\text { method }\end{array}$ & 0.842 & Positive \\
\hline 3. & $\begin{array}{c}3, \\
\text { farm no. } 1\end{array}$ & $\begin{array}{l}\text { reverse feeding } \\
\text { method }\end{array}$ & 1.090 & Positive \\
\hline 4. & $\begin{array}{c}4, \\
\text { farm no. } 1\end{array}$ & $\begin{array}{l}\text { reverse feeding } \\
\text { method }\end{array}$ & 0.486 & Positive \\
\hline 5. & $\begin{array}{c}5, \\
\text { farm no. } 1\end{array}$ & $\begin{array}{l}\text { reverse feeding } \\
\text { method }\end{array}$ & 2.196 & Positive \\
\hline 6. & $\begin{array}{c}1, \\
\text { farm no. } 2\end{array}$ & $\begin{array}{l}\text { immunization with } \\
\text { inactivated vaccine }\end{array}$ & 0.570 & Positive \\
\hline 7. & $\begin{array}{c}2, \\
\text { farm no. } 2\end{array}$ & $\begin{array}{l}\text { immunization with } \\
\text { inactivated vaccine }\end{array}$ & 0.084 & Negative \\
\hline 8. & $\begin{array}{c}3, \\
\text { farm no. } 2\end{array}$ & $\begin{array}{l}\text { immunization with } \\
\text { inactivated vaccine }\end{array}$ & 1.689 & Positive \\
\hline 9. & $\begin{array}{c}4, \\
\text { farm no. } 2\end{array}$ & $\begin{array}{l}\text { immunization with } \\
\text { inactivated vaccine }\end{array}$ & 2.256 & Positive \\
\hline 10. & $\begin{array}{c}5, \\
\text { farm no. } 2\end{array}$ & $\begin{array}{l}\text { immunization with } \\
\text { inactivated vaccine }\end{array}$ & 0.097 & Negative \\
\hline 11. & $\begin{array}{c}6, \\
\text { farm no. } 2\end{array}$ & $\begin{array}{l}\text { immunization with } \\
\text { inactivated vaccine }\end{array}$ & 0.912 & Positive \\
\hline 12. & $\begin{array}{c}7, \\
\text { farm no. } 2\end{array}$ & $\begin{array}{l}\text { immunization with } \\
\text { inactivated vaccine }\end{array}$ & 1.116 & Positive \\
\hline
\end{tabular}

Note. Here and further: Positive $->0,374 \mathrm{~K} «+»-0.932 ; 0.995$; Negative $-<0,374 \mathrm{~K} \ll-»-0.013 ; 0.019 ; 0.041=0.024$. 
disease control should be balanced and grounded on the objective premises. Usually inactivated vaccines have the advantage, reducing the likelihood and subsequently negating the possibility of the circulation of the PED virus in the pig population. In the same two farms, an experiment to determine the presence of antibodies to the PED pathogen in the sow's colostrum in dynamics was conducted. An experimental sample of the inactivated vaccine was used. Samples of colostrum were collected in 1 hour, 4 hours and 10 hours after farrowing (table 3 ).

Table 3. The results of studies of maternal antibodies titers $(\lg A)$ in the colostrum of sows in the dynamics

\begin{tabular}{|c|c|c|c|c|}
\hline \multirow{2}{*}{ No. } & \multirow{2}{*}{$\begin{array}{l}\text { No. of sow, } \\
\text { no. of farm }\end{array}$} & \multirow{2}{*}{$\begin{array}{c}\text { Time } \\
\text { after } \\
\text { farrow, } \\
\text { hours }\end{array}$} & \multicolumn{2}{|c|}{$\begin{array}{c}\text { Colostral antibody } \\
\text { titer }\end{array}$} \\
\hline & & & $\begin{array}{l}\text { Optical } \\
\text { dencity }\end{array}$ & Result \\
\hline 1. & $\begin{array}{l}\text { inv. no. } 7598 \\
\text { farm no. } 1\end{array}$ & $1 \mathrm{hr}$ & 0.745 & Positive \\
\hline 2. & $\begin{array}{l}\text { inv. no. } 7598 \\
\text { farm no. } 1\end{array}$ & $4 \mathrm{hr}$ & 0.343 & Negative \\
\hline 3. & $\begin{array}{l}\text { inv. no. } 7598 \\
\text { farm no. } 1\end{array}$ & $10 \mathrm{hr}$ & 0.495 & Positive \\
\hline 4. & $\begin{array}{l}\text { inv. no. } 7954 \\
\text { farm no. } 1\end{array}$ & $1 \mathrm{hr}$ & 0.064 & Negative \\
\hline 5. & $\begin{array}{l}\text { inv. no. } 7954 \\
\quad \text { farm no. } 1\end{array}$ & $4 \mathrm{hr}$ & 0.276 & Negative \\
\hline 6. & $\begin{array}{l}\text { inv. no. } 7954, \\
\text { farm no. } 1\end{array}$ & $10 \mathrm{hr}$ & 0.204 & Negative \\
\hline 7. & $\begin{array}{l}\text { inv. no. } 7874, \\
\text { farm no. } 1\end{array}$ & $1 \mathrm{hr}$ & 0.229 & Negative \\
\hline 8. & $\begin{array}{l}\text { inv. no. } 7874, \\
\text { farm no. } 1\end{array}$ & $4 \mathrm{hr}$ & 0.212 & Negative \\
\hline 9. & $\begin{array}{l}\text { inv. no. } 7874 \text {, } \\
\text { farm no. } 1\end{array}$ & $10 \mathrm{hr}$ & 1.168 & Positive \\
\hline 10. & $\begin{array}{l}\text { inv. no. } 9152, \\
\text { farm no. } 2\end{array}$ & $1 \mathrm{hr}$ & 0.467 & Positive \\
\hline 11. & $\begin{array}{l}\text { inv. no. } 9152, \\
\text { farm no. } 2\end{array}$ & $4 \mathrm{hr}$ & 0.477 & Positive \\
\hline 12. & $\begin{array}{l}\text { inv. no. } 9152, \\
\text { farm no. } 2\end{array}$ & $10 \mathrm{hr}$ & 0.484 & Positive \\
\hline 13. & $\begin{array}{l}\text { inv. no. } 2518, \\
\text { farm no. } 2\end{array}$ & $1 \mathrm{hr}$ & 0.503 & Positive \\
\hline 14. & $\begin{array}{l}\text { inv. no. } 2518, \\
\text { farm no. } 2\end{array}$ & $4 \mathrm{hr}$ & 0.142 & Negative \\
\hline 15. & $\begin{array}{l}\text { inv. no. } 2518 \\
\quad \text { farm no. } 2\end{array}$ & $10 \mathrm{hr}$ & 0.018 & Negative \\
\hline 16. & $\begin{array}{l}\text { inv. no. } 5672, \\
\text { farm no. } 2\end{array}$ & $1 \mathrm{hr}$ & 0.316 & Negative \\
\hline 17. & $\begin{array}{l}\text { inv. no. } 5672, \\
\text { farm no. } 2\end{array}$ & $4 \mathrm{hr}$ & 0.180 & Negative \\
\hline 18. & $\begin{array}{l}\text { inv. no. } 5672, \\
\text { farm no. } 2\end{array}$ & $10 \mathrm{hr}$ & 0.275 & Negative \\
\hline
\end{tabular}

\section{Conclusion}

Epidemic diarrhea of pigs remains a problem for pig industry in many countries around the world, including Ukraine. Since the efficacy of the commercially available PED vaccines has not been confirmed, our developed preparation remains an effective method of preventing the disease with advantage in using local strains of the pathogen.

\section{Prospects of Further Research}

The research results proved the effectiveness of the inactivated vaccine against PED on the base of the intestinal virus antigens infected dairy-free piglets. It was detected the presence of maternal antibodies against PED pathogen in colostrum during the first hours after farrowing. The absence of antibodies in some test samples of sow colostrum was associated with the individual physiological condition of the organism, the possibility of their appearance at a longer period after farrowing, which is the task of further research.

1. Carr J, Howells M. Virulent PEDV in Ukraine - what happened on farm. Pig Progress. 2015; 31 (3): 8-11.

2. Chen Q, Li G, Stasko J, Thomas JT, Stensland WR, Pillatzki AE, Gauger PC, Schwartz KJ, Madson D, Yoon KJ, Stevenson GW, Burrough ER, Harmon KM, Main RG, Zhang J. Isolation and characterization of porcine epidemic diarrhea viruses associated with the 2013 disease outbreak among swine in the United States. J. Clin Microbiol. 2014; 52 (1): 234-43. DOI: 10.1128/ JCM.02820-13.

3. Dee S. Control and eradication of porcine reproductive and respiratory syndrome. Compend Cont Educ Pract Vet. 2000; 22: 27-35.

4. Havrylenko AV, Nedosyekov VV. Epidemic diarrhea of pigs: approaches to prevention and control. Veterinary Medicine of Ukraine. 2015; 8 (234): 7-10. Available at: http://base.dnsgb.com.ua/ files/journal/Veterinarna-medicina-Ukrainy/VMU-2015-08/2.pdf (in Ukrainian)

5. Meier WA, Wheeler J, Husmann RJ, Osorio FA, Zuckermann FA. Characteristics of the immune response of pigs to wild-type PRRS virus or to commercially available vaccines: an unconventional response. Proc. Am. Assoc. Swine Practition. Indianapolis, Indiana, USA; 2000: 415-418.

6. Nedosekov V. Infectious animal pathology: problems and prospects. Earth Biores. Qual. Life. 2012; 1. Available at: https:// gchera-ejournal.nubip.edu.ua/index.php/ebql/article/view/14

7. Orljankin BG. Antiviral immunity and a strategy for the specific prevention of viral diseases of pigs. Materials Intern. Scientific conf.; Federal state institure. Vladimir, ARRIAH: 2008; 129-145. (in Russian)

8. Swine Enteric Coronavirus Disease Testing Summary Report. NAHLNLabs, 2014. Available at: https://www.aasv.org/pedv/ SECoV_weekly_report_140604.pdf

9. Wang L, Byrum B, Zhang Y. New variant of porcine epidemic diarrhea virus. Emerg. Infect. Diseases. 2014; 20 (5): 917-919. DOI: 10.3201/eid2005.140195. 


\section{Аналіз стану колострального імунітету поросят за імунізації свиноматок проти вірусу епідемічної діареї свиней}

О. Є. Айшпур, І. Ю. Муштук, Л. М. Музикіна, О. А. Тарасов, О. М. Єрмоленко, В. В. Гуменюк, М. М. Дерев'янко olenaayshpur@gmail.com, mushtuk0104@gmail.com

Інститут ветеринарної медицини НААН,

вул. Донецька, 30, м. Київ, 03151, Україна

Епідемічна діарея свиней (ЕДС) - гостре, надзвичайно контагіозне вірусне захворювання свиней усіх вікових груп, яке характеризується рвотою, діареєю і відсутністю апетиту і спричиняє особливо високу смертність серед новонароджених поросят. ЕДС залишається проблемою для господарств-виробників свинини у багатьох країнах світу, зокрема в Україні. Специфічна профілактика ЕДС виявилася важким завданням, яке, попри численні дослідження, і надалі залишається невирішеним. Оскільки поросята хворіють у перші дні після народження, їхній захист може бути забезпечений тільки колостральними антитілами від імунізованих свиноматок. Отже, нагальним завданням науковців ветеринарної медицини є розробка ефективних методів профілактики захворювання, що полягає у використанні місцевих штамів збудника. Представлені результати досліджень колострального імунітету поросят визначенням наявності антитіл проти вірусу ЕДС в молозиві свиноматок, імунізованих вакциною, інактивованою проти ЕДС з кишкового вірусу штучно заражених безмолозивних поросят. Інфекційну активність матричних розплодок вірусу для виробництва препарату визначали методом ПЛР-РЧ. За результатами досліджень відбирали матеріал для виготовлення вакцини. Надалі препарат контролювали згідно з технологічним регламентом, зокрема інфекційну

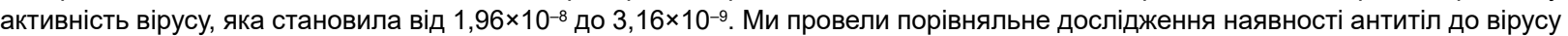
ЕДС в молозиві свиноматок методом «зворотнього згодовування» і вакцинації свиноматок інактивованим препаратом. Зразки молозива від свиноматок відбирали впродовж 1-4 год. після опоросу. Результати засвідчили, що обидва методи обробки свиноматок створюють імунітет у новонароджених тварин. Наявність антитіл до вірусу ЕДС в молозиві вже у перші години після народження забезпечує захист від інфікування та загибелі поросят.

Ключові слова: вірус, ЕДС, свині, колостральной імунітет, молозиво

Ayshpur OY, Mushtuk IY, Muzykina LM, Tarasov OA, Yermolenko OM, Gumeniuk VV, Derevyanko MM. The analysis of the condition of colostral immunity of sows after vaccination against porcine epidemic diarrhea virus. Biol. Tvarin. 2021; 23 (1): 3-6.

DOI: 10.15407/animbiol23.01.003. 